\title{
Mark D. Bertness, Atlantic Shorelines, Natural History and Ecology
}

\author{
Princeton University Press, Woodstock, UK, 2007, 446 pp, ISBN (paper) \\ 0-691-12554-6 USD 99.50, GBP 65.00, USD 45.00, GBP 29.95 ISBN (cloth) \\ 0-691-12553-8
}

\author{
Gerhard C. Cadée
}

Published online: 23 May 2007

(C) Springer Science+Business Media B.V. 2007

Atlantic shorelines, is an easily readable introduction to coastal ecology, aimed at undergraduate students as well as a broader interest public. It avoids, as much as possible, jargon and mathematical formulas, and modeling is absent as well.

This might be one of the last textbooks on marine ecology (albeit only dealing with coastal ecosystems), written by one author. With an increase in knowledge it will become more and more difficult to overview the entire field. The advantage is of course that one author might produce a well-balanced and well-structured book. The first four chapters deal with the geological and physical forces that shaped the North American Atlantic coastal habitats, trophic relations, reproduction and recruitment of organisms, and processes that influence distribution (zonation). The last three chapters deal with habitats: rocky shores, soft-sediment habitats, and the salt marsh and mangrove habitats. Each chapter concludes with a very useful one-page summary and some suggestions for further reading. A glossary of seven pages gives short descriptions of the terminology used. A long reference list of some 750 titles (from which Bertness himself was author or coauthor of almost 10\%) and an index complete the book.

\section{G. C. Cadée $(\bowtie)$}

Royal Neth. Inst Sea Research, P.O. Box 59, 1790 AB

Den Burg, The Netherlands

e-mail: cadee@nioz.nl
A textbook, written by one author has also its shortcomings, one cannot be an expert in all fields. So on page 37 , phytoplankton is stated to consist of diatoms and dinoflagellates only, whereas cyanobacteria and other flagellates may be dominant and bloom-forming such as the colonial Phaeocystis and the nanoplanktonic chrysophyte Aureococcus causing 'brown tides' along the American Atlantic coast (Laguna Madre, Long Island Sound, Narragansett Bay). The reader will also not learn about Archaea that appear to be present in large numbers also in coastal waters. The microbial loop in the food chains is not dealt with and microphytobenthos is not mentioned as important primary producers in tidal flat areas in this chapter (they are mentioned on p. 247). I do not understand why (p. 42) decaying algae accumulate on the seafloor below the euphotic zone in the absence of primary producers? Does Bertness mean that primary consumers (including bacteria) are few or absent here when the accumulation is too high and the bottom becomes anoxic? The maximum depth below which marine photosynthetic plants cannot survive is not named compensation depth (p. 40 and fig. 2.4). The text in the glossary is okay, at the compensation depth photosynthesis rate equals respiration rate (over 24 hours) and there is no net growth. However, algae can survive well below the compensation depth and do so either for short periods, e.g., during strong vertical turbulence or for longer periods as dormant cells or in the form of cysts. Dinoflagellates may even actively commute 
between the deeper nutrient-rich waters and the welllit surface waters.

Bryozoans are not 'passive' filterfeeders (p. 56). Ryland (1970), cited by Bertness, clearly indicates how active cilia cause a current flow through the tentacles. Is it true that most modern bryozoans evolved heavy calcium carbonate armor? (p. 75) There are also highly successful modern anascan bryozoans, with a simple frontal membrane. Among the bird predators mentioned on several pages (75, 266, 283) I missed the role of waders, e.g., knots and oystercatchers and ducks such as eiders and scoters, all highly successful molluscivores, but I may be biased because of my experience in the Dutch coastal area. On p. 285 the increasing hypoxia events are considered as the cause of impacting American Atlantic shorelines, but it is not mentioned what causes these events, nor is it mentioned in the short paragraphs on conservation of the coastal environment.

In the book preface, the author states Atlantic Shorelines to be an updated revision of his book The Ecology of Atlantic Shorelines published in 1998. Only some $10 \%$ of the references cited date from after 1997, which suggests (wrongly?) a decline in papers published on American Atlantic shorelines since a blooming period in the 1980s and 1990s. Moreover, not all the text is updated: on p. 88 is referred to research 'in the last decade', but the most recent paper cited dates from 1995. On p. 118 'more recent work' refers to work published between 1979 and 1993 and on p. 121 one wonders whether 'to date' no more recent experimental work has been published on larval habitat selection after 1988. This all is a bit sloppy, if not careless.

The many drawings, new or redrawn from the original publications, help to understand the text.
However, sometimes they are too roughly redrawn: one will not recognize a nematode in figures 6.7 and 6.8 , nor is the ostracod in these figures very identifiable. The figure 6.23 , stated to be redrawn from Olafsson (1986), shows an unrecognizable Macoma balthica. It has got oral food palps to collect surface sediment, in order to fit in the text on p. 257 where Bertness states that M. balthica is a protobranch bivalve using oral palps just like Yoldia. Of course, it is not a protobranch but a tellinid, and it collects surface sediment with its siphons! The whelk Busycon changes in one figure (6.25) from rightcoiled (upper figure) to left-coiled in the lower one. Who will recognize in the two very similar looking bivalves in fig 6.41 a Macoma in the upper panel and a Mya in the lower one? I have often seen sand deposition around a glass bottle on the beach, but not as depicted in fig. 6.51. On Dutch beaches, usually the bottles lay flat on one side, the other side remains uncovered and becomes sand-blasted.

Although the Atlantic Ocean stretches from the Arctic to the Antarctic, the book deals only with the Atlantic shorelines of North America and this constraint might have been added to the (sub)title of the book. It is apparently mainly written for American public, and for this it is of course an advantage that most of the examples given can be studied within the USA.

The book does contain much useful information, however, as indicated above, it also contains errors and inaccuracies that could have been avoided, probably by inviting competent coauthors for editorial help. Instead of the 69 color plates mentioned in the press release, my copy has 66 color pictures on a 16-pages insert. 